\title{
Vertical migratory response of benthic foraminifera to controlled oxygen concentrations in an experimental mesocosm
}

\author{
Elisabeth Alve ${ }^{1}$, Joan M. Bernhard ${ }^{2}$ \\ ${ }^{1}$ Department of Geology, University of Oslo, PO Box 1047 Blindern, N-0316 Oslo, Norway \\ ${ }^{2}$ Wadsworth Center for Laboratories and Research, PO Box 509, Albany, New York 12201-0509, USA
}

\begin{abstract}
This experimental study investigated the vertical migratory response of benthic foraminifera in sediments that were initially oxygenated, to variations in dissolved-oxygen concentrations ranging from well-oxygenated to dysaerobic conditions. Two box cores, with a carpet of polychaete tubes extending above the sediment-seawater interface, were recovered from $71 \mathrm{~m}$ water depth in Oslofjord, southern Norway. The seawater oxygen concentration of one box core was decreased every $4 \mathrm{wk}$, to a minimum value of $<0.2 \mathrm{ml} \mathrm{O}_{2} \mathrm{I}^{-1}$. Aerated seawater circulation was maintained in the other (control) box core. In a time course, 2 subcores were taken from each mesocosm every 4 wk and sectioned in $0.5 \mathrm{~cm}$ intervals to depths of $2.0 \mathrm{~cm}$, and $1.0 \mathrm{~cm}$ intervals from 2.0 to $4.0 \mathrm{~cm}$. The portion of the polychaete tubes extending into the overlying water was collected and treated as an additional sample. Live foraminiferal distributions were examined in the $>63 \mu \mathrm{m}$ fraction of each interval shallower than $2 \mathrm{~cm}$ using both an ATP assay and a rose Bengal staining method, while only rose Bengal was used to assess distributions from 2 to $4 \mathrm{~cm}$. Results indicate that larger numbers of live and stained foraminifera are found on the polychaete tubes and in the superficial $0.5 \mathrm{~cm}$ of sediment after exposure to dysaerobic conditions compared to original and control abundances. After re-oxygenation for $4 \mathrm{mo}$, the foraminifera re-migrated into the sediments, exhibiting distributions similar to those of the control mesocosm. These observations suggest that some species actively migrate to a microenvironment with a particular oxygen concentration, rather than maintaining a stable position with respect to the sediment-water interface.
\end{abstract}

KEY WORDS: Foraminiferal vertical migration - Hypoxia $\cdot$ Mesocosm $\cdot$ Behavior $\cdot$ Re-oxygenation

\section{INTRODUCTION}

Benthic foraminifera (Protista: Sarcodina) are ubiquitous members of most marine environments (reviewed in Murray 1991) and the dominant meiofaunal group in some areas (e.g. the deep sea; Coull et al. 1977, Shirayama 1984, Gooday 1986). It is now well established that this taxonomic group has infaunal as well as epifaunal species (e.g. Corliss 1985, Gooday 1986, Linke \& Lutze 1993). The infauna have been further subdivided into shallow-, intermediate-, and deepdwelling species (e.g. Corliss 1991), some of which are thought to be facultative anaerobes (Bernhard \& Reimers 1991, Moodley \& Hess 1992, Bernhard 1993, Sen Gupta \& Machain-Castillo 1993, Alve 1994). How- ever, a better understanding of the forces which drive benthic foraminiferal vertical distributions is important, particularly for studies of marine benthic community dynamics, pollution, and paleoceanography. For instance, in sediments where benthic foraminifera are dominant and/or abundant (e.g. the deep sea, oxygendepleted environments, organically polluted areas), they are likely to play an active role in structuring the benthic ecosystem, as observed in the deep sea (Gooday 1994). Foraminiferal distributions have been used to monitor the extent and magnitude of organic pollution (Alve 1995) but an increased understanding of foraminiferal response to depleted dissolved oxygen concentrations, caused, for instance, by eutrophication, will further refine these approaches. Studies which use 
broad-scale benthic foraminiferal distributions (e.g. Koutsoukos et al. 1990, Kaiho 1991), test (shell) morphologies (Nagy 1992), and test stable isotopic signatures to interpret paleoenvironmental conditions will also greatly benefit from such knowledge. The fact that foraminifera inhabit a variety of microhabitats with respect to vertical distributions within, on, and above sediments permits the use of the $\delta^{13} \mathrm{C}$ signal in the tests of certain calcareous species to infer various paleoceanographic properties (e.g. paleocirculation, paleoproductivity; reviewed in Altenbach \& Sarnthein 1989). Because the $\delta^{13} \mathrm{C}$ signal reflects, among other things, the chemical properties of the microhabitat where a specimen calcified (Mackensen \& Douglas 1989, McCorkle et al. 1990), it is of crucial importance to determine the microhabitat where different foraminiferal species reside.

Most studies investigating foraminiferal ecology and microhabitat distributions sample specimens and various environmental parameters in an area at one given time (e.g. Hermelin \& Shimmield 1990, Bernhard 1992, Jorissen et al. 1992). While recent progress has been made in establishing general vertical distribution patterns for some species (e.g. Corliss 1991), information is needed concerning the vertical migratory patterns of the foraminifera over time (e.g. seasonally, ontogenetically) as well as the environmental factors which control an individual specimen's position within sediments. In other words, are infaunal specimens transient or permanent inhabitants of a particular sediment horizon? If transient, do they follow a particular microenvironment? Oxygen concentration and food availability (i.e. organic carbon content) have been suggested as the primary driving forces of foraminiferal vertical distributions (e.g. Bernhard 1992, Linke \& Lutze 1993) but an ongoing debate remains concerning which factor is more important (e.g. Rathburn \& Corliss 1994). One field study which sampled the same area over time concluded that some species which are generally considered to be infaunal migrate to the sediment surface during periods of oxygen depletion (Barmawidjaja et al. 1992). However, in the natural environment, oxygen concentration and organic carbon content are inherently linked since an increase in organic carbon can indirectly cause a decrease in oxygen concentration. Consequently, it is difficult to isolate the influence of each parameter upon foraminiferal distribution (Altenbach \& Sarnthein 1989, Sjoerdsma \& van der Zwaan 1992). Our working hypothesis was that dissolved oxygen concentration drives foraminiferal vertical distributions. This was tested by controlling the dissolved oxygen concentration in boxcore mesocosms of similar organic carbon concentrations. Vertical distributions of naturally composed foraminiferal assemblages were analyzed after extended exposure to known oxygen concentrations.

\section{METHODS}

Two $0.25 \mathrm{~m}^{2}$ box cores were recovered on 8 October 1992 from $71 \mathrm{~m}$ water depth in the inner Oslofjord, Norway $\left(59^{\circ} 44.28^{\prime} \mathrm{N}, 10^{\circ} 31.75^{\prime} \mathrm{E}\right)$. Typically, this area is bathed in bottom waters with oxygen concentrations of $>3 \mathrm{ml} \mathrm{l}^{-1}$ (i.e. $>130 \mu \mathrm{M} \mathrm{kg}^{-1}$ ) but concentrations may occasionally drop below $1 \mathrm{ml}^{-1}$ (J. Magnusson written comm. 1994). Temperature and salinity fluctuate annually between $\sim 7$ and $10^{\circ} \mathrm{C}$ and 32.5 and $33.8 \%$, respectively (Magnusson written comm. 1994).

Prior to deployment of the UNSEL-Mark 5 type boxcorer, a snug-fitting plexiglass liner was installed inside the core barrel. After recovery, the core bottom was sealed off by sliding a plate of PVC across the bottom of the core as the spade was slowly opened. The sediment-filled plexiglass core liner was then removed from the boxcorer, fastened with a temporary lid, and transported via ship to the Norwegian Institute for Water Research (NIVA) Solbergstrand marine station. The experiment was conducted in a cool, darkened laboratory equipped with running fjord seawater pumped from $40 \mathrm{~m}$ water depth.

While some studies show that alternative sampling devices retrieve less-disturbed samples than box cores (Chandler et al. 1988, Bett et al. 1994), our box cores had clear overlying waters, probably because the sediments were anchored by the polychaete-tube lawn (see below). Furthermore, since the control and experimental mesocosms were collected in an identical manner, the possibility that the samples were disturbed is of little consequence to the experimental design. Spatial pseudoreplication, however, poses more of a concern regarding our experimental design (Hurlbert 1984). While the time-dependent nature of our sampling scheme and analyses prohibited the inclusion of more than 2 mesocosms in our study, the inclusion of a control mesocosm in our design helps to alleviate the charges of pseudoreplication.

One mesocosm was continuously circulated with the seawater pumped directly from the fjord, and, therefore, was considered the aerated control. The other (experimental) mesocosm also had continuous circulation but the oxygen concentration of the seawater was manipulated to desired levels by flushing the incoming seawater with nitrogen (Fig. 1). After a sampling event (Table 1), the oxygen concentration of the mesocosm was manipulated to the desired level over a period of 24 to $48 \mathrm{~h}$. The oxygen concentration of the experimental mesocosm was decreased to a minimum $\left(<0.2 \mathrm{ml} \mathrm{O}_{2} \mathrm{l}^{-1}\right)$ over $3 \mathrm{mo}$ and maintained at $<0.2 \mathrm{ml} \mathrm{O}_{2} \mathrm{l}^{-1}$ for an additional $5 \mathrm{wk}$, at which time it was aerated over another $4 \mathrm{mo}$. The oxygen concentration of the water was continuously monitored with a permanently installed YSI oxygen probe (type 518) connected to a model 58 oxygen meter. 


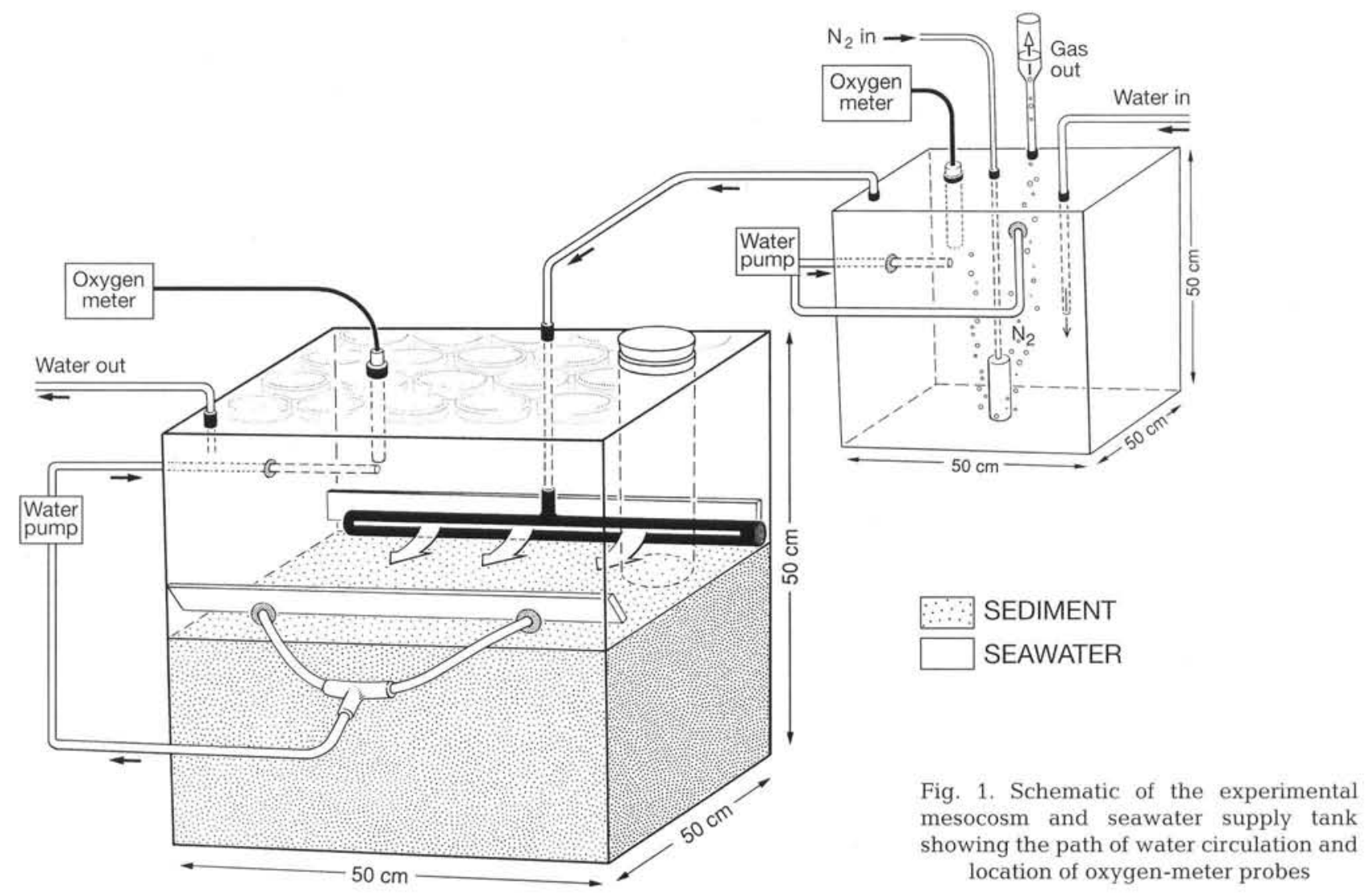

The major steps executed during each sampling event are shown in Fig. 2. During each sampling event, 2 subcores (denoted A and B, $4.6 \mathrm{~cm}$ inner diameter) were taken from each box core. When a subcore was taken, 2 nested core liners were simultaneously pressed into the sediments. The outer, larger diameter liner remained in the sediments to prevent slumping while the smaller diameter subcore was capped and removed for

Table 1. Date, oxygen concentration, temperature, and salinity for the experimental mesocosm for each sampling event. Temperature and salinity data are the same for both mesocosms and reflect the average value for the period just after the preceding sampling event until the given sampling event. Oxygen data are Winkler results taken on the specified date, but similarly reflect the values for the periods just after the preceding sampling event until the given sampling event

\begin{tabular}{|ccccc|}
\hline $\begin{array}{c}\text { Sampling } \\
\text { event }\end{array}$ & Date & $\begin{array}{c}\text { Oxygen } \\
\left(\mathrm{ml} \mathrm{1}^{-1}\right)\end{array}$ & $\begin{array}{c}\text { Temperature } \\
\left({ }^{\circ} \mathrm{C}\right)\end{array}$ & $\begin{array}{c}\text { Salinity } \\
(\% \circ)\end{array}$ \\
\hline 1 & 15 Oct 1992 & $>3.0$ & 9.8 & 33.9 \\
2 & 23 Nov 1992 & 2.0 & 10.5 & 33.7 \\
3 & 21 Dec 1992 & 1.3 & 9.0 & 33.2 \\
4 & 18 Jan 1993 & 0.7 & 8.4 & 33.0 \\
5 & 4 Feb 1993 & $<0.2$ & 8.4 & 32.6 \\
6 & 22 Feb 1993 & $<0.2$ & 7.4 & 34.4 \\
7 & 20 Jun 1993 & $>3.0$ & 7.1 & 34.3 \\
\hline
\end{tabular}

processing. In the experimental box core, access to the mesocosm was through tightly capped sampling ports that were machined into the lid. Thus, when a subcore was taken, the mesocosm was exposed to atmospheric conditions only for a very brief time (i.e. $<3 \mathrm{~s}$ ). Since the outer subcore liner remaining in the mesocosms must have affected the pattern of water circulation, initial subcores were taken near the side of the mesocosm opposite the inflow. Subsequent subcores were taken progressively closer to the water inflow. During each sampling event, those portions of polychaete tubes extending into the overlying water in the subcores were collected and treated separately. The polychaete tubes were severed at the sediment-water interface using fine microscopy forceps and live-insect-collecting forceps. The ATP from each foraminifer found on the polychaete tubes within about 30 min was extracted. Tube remains were preserved in $70 \%$ ethanol and subsequently treated as a separate sediment sample, as described below.

After the polychaete tube sample was obtained, each sediment subcore was sectioned in $0.5 \mathrm{~cm}$ intervals to a depth of 
(I) Sample mesocosm

(A) Sample water for Winkler titration

(B) Subcore A taken

(1) Obtain polychaete sample

(2) Section subcore from $0-4 \mathrm{~cm}$

(3) Preserve intervals in ethanol

(C) Subcore B taken

(1) Obtain polychaete sample

(2) Section 0-4 cm

(3) Maintain intervals from $0-2 \mathrm{~cm}$ in chilled seawater

(4) Preserve $2-4 \mathrm{~cm}$ intervals in ethanol

(5) Sieve 0-2 cm intervals over $63 \mu \mathrm{m}$ screen with chilled seawater

(6) Pick and extract foraminifera from polychaete-tube sample

(7) Pick 0-2 cm intervals, extract obtained specimens for ATP (100 per interval)

(8) Preserve remaining $0-2 \mathrm{~cm}$ interval samples in ethanol

(II) Sample control mesocosm

(A) Repeat (I)(B) through (C)

(III) Increase $\mathrm{N}_{2}$ in header tank to experimental mesocosm

(IV) Process preserved samples $(\geq 250$ stained specimens per interval) and analyze ATP extracts

Fig. 2. Outline of tasks executed during each sampling event

$2.0 \mathrm{~cm}$, and $1.0 \mathrm{~cm}$ intervals from 2.0 to $4.0 \mathrm{~cm}$. The sediments recovered from 0 to $2 \mathrm{~cm}$ in the B subcores were sieved with ambient temperature seawater over $63 \mu \mathrm{m}$ screens and maintained at $\sim 5^{\circ} \mathrm{C}$. The $>63 \mu \mathrm{m}$ fraction was kept on ice and examined for foraminifera using a Zeiss stereoscope. A total of 100 specimens were recovered from each sediment interval from 0 to $2 \mathrm{~cm}$ using a mouth pipette. The length of each specimen was recorded just prior to its extraction for ATP, following the procedure of Bernhard (1992). ATP extracts were frozen $\left(-35^{\circ} \mathrm{C}\right)$ until analyzed via luciferase reaction on an LKB 1250 luminometer. Remaining sediments were preserved in $70 \%$ ethanol and refrigerated until further processing with rose Bengal (see below). During sampling events 5 and 6 , specimens were not extracted for ATP from the depth interval 1.5 to $2.0 \mathrm{~cm}$ due to logistical complications. Data were analyzed following the procedure of Bernhard (1992), where specimens with $>149 \mathrm{ng}$ ATP $\mathrm{mm}^{-3}$ test volume were considered to be alive at the time of extraction. Sediment intervals deeper than $2 \mathrm{~cm}$ were preserved in ethanol soon after sampling and processed using only the rose Bengal method.

Ethanol-preserved sediments were sieved over a $63 \mu \mathrm{m}$ screen, stained with rose Bengal for 8 to $14 \mathrm{~h}$, and dried at $50^{\circ} \mathrm{C}$. While $45 \mu \mathrm{m}$ or smaller sieves are used in many meiofaunal studies, the use of a $63 \mu \mathrm{m}$ sieve is consistent with most foraminiferal ecology studies (see e.g. Sen Gupta et al. 1987). When possible, at least 250 stained specimens were picked from a known portion of each sample and the total number was calculated. The subsequent use of the terms 'live' and 'stained' refer to specimens which were determined to be live by the ATP method and those which were stained with rose Bengal, respectively.

Examination of the data on the stained foraminifera from B subcores from the control box core suggested that variability in numerical density between subcores occurred (i.e. horizontal patchiness; Table 2). However, vertical distribution patterns were surprisingly consistent (Table 2). In the single set of replicate subcores analyzed for the control mesocosm, the vertical distributions were similar between subcores. Therefore, for the aerated control, only 1 subcore was

Table 2. Down-core numerical density of stained foraminifera (number stained $\mathrm{cm}^{-3}$ ) for the control (CA and CB) and experimental (EA and EB) mesocosms for each sampling event

\begin{tabular}{|c|c|c|c|c|c|}
\hline \multirow{2}{*}{$\begin{array}{l}\text { Sampling } \\
\text { event }\end{array}$} & \multirow{2}{*}{$\begin{array}{c}\text { Depth } \\
\text { interval }(\mathrm{cm})\end{array}$} & \multicolumn{4}{|c|}{ Density } \\
\hline & & $\mathrm{CA}$ & $\mathrm{CB}$ & EA & EB \\
\hline \multirow[t]{7}{*}{1} & Tubes & - & 2.2 & - & 1.2 \\
\hline & $0.0-0.5$ & - & 21.6 & - & 42.8 \\
\hline & $0.5-1.0$ & - & 13.0 & - & 20.2 \\
\hline & $1.0-1.5$ & - & 11.7 & - & 18.1 \\
\hline & $1.5-2.0$ & - & 6.9 & - & 17.3 \\
\hline & $2.0-3.0$ & - & 4.2 & - & 21.4 \\
\hline & $3.0-4.0$ & - & 1.5 & - & 19.5 \\
\hline \multirow[t]{7}{*}{2} & Tubes & - & 1.5 & - & 0.4 \\
\hline & $0.0-0.5$ & - & 26.7 & 35.1 & 19.3 \\
\hline & $0.5-1.0$ & - & 13.7 & 15.8 & 10.2 \\
\hline & $1.0-1.5$ & - & 10.2 & 12.0 & 11.8 \\
\hline & $1.5-2.0$ & - & 5.2 & 8.9 & 8.1 \\
\hline & $2.0-3.0$ & - & 4.0 & 4.2 & 3.7 \\
\hline & $3.0-4.0$ & - & 2.0 & 1.4 & 2.4 \\
\hline \multirow[t]{7}{*}{5} & Tubes & - & 1.0 & 4.1 & 3.9 \\
\hline & $0.0-0.5$ & - & 37.0 & 29.2 & 93.8 \\
\hline & $0.5-1.0$ & - & 15.6 & 8.9 & 12.6 \\
\hline & $1.0-1.5$ & - & 11.9 & 7.6 & 12.1 \\
\hline & $1.5-2.0$ & - & 8.2 & 8.3 & 10.5 \\
\hline & $2.0-3.0$ & - & 4.2 & 3.4 & 5.3 \\
\hline & $3.0-4.0$ & - & 2.4 & 1.8 & 1.1 \\
\hline \multirow[t]{7}{*}{6} & Tubes & 0.1 & 0.9 & 15.0 & 33.0 \\
\hline & $0.0-0.5$ & 12.3 & 24.6 & 40.1 & 31.3 \\
\hline & $0.5-1.0$ & 6.0 & 9.0 & 4.3 & 2.5 \\
\hline & $1.0-1.5$ & 8.4 & 3.8 & 2.5 & 1.6 \\
\hline & $1.5-2.0$ & 10.1 & 5.1 & 1.0 & 1.6 \\
\hline & $2.0-3.0$ & 6.6 & 2.4 & 1.6 & 0.8 \\
\hline & $3.0-4.0$ & 3.9 & 1.7 & 4.6 & 0.7 \\
\hline \multirow[t]{7}{*}{7} & Tubes & - & 1.4 & 6.0 & 3.3 \\
\hline & $0.0-0.5$ & - & 28.2 & 198.1 & 34.7 \\
\hline & $0.5-1.0$ & - & 9.3 & 52.5 & 27.9 \\
\hline & $1.0-1.5$ & - & 9.3 & 19.0 & 15.2 \\
\hline & $1.5-2.0$ & - & 9.1 & 9.3 & 6.6 \\
\hline & $2.0-3.0$ & - & 2.9 & 3.4 & 2.4 \\
\hline & $3.0-4.0$ & - & 2.9 & 1.8 & 1.4 \\
\hline
\end{tabular}


processed for each of the remaining sampling events analyzed. Horizontal patchiness of stained foraminifera was more apparent in the experimental subcores (Table 2). Therefore, in order to assure that vertical distributional patterns were consistent in the experimental mesocosm, replicate subcores were counted in all but one of the analyzed sampling events. Sampling events 3 and 4 were not analyzed because the results did not indicate any drastic changes (in terms of vertical patterns) between sampling events 2 and 5 .

After sampling event 2, dissolved oxygen concentrations were empirically determined by standard Winkler titration, to provide independent calibration of the oxygen probe. Total organic carbon analyses was determined by the LECO combustion method on a third set of subcores collected during sampling event 7 . Water content was calculated as the percentage of weight loss after drying of the wet sediment at $50^{\circ} \mathrm{C}$.

\section{RESULTS}

At the time of collection, both box cores had spionid polychaete lawns with tube densities of about 2 to $3 \mathrm{~cm}^{-2}$. Sediments were light to dark brown muddy silt. A distinct color change to black occurred deeper than $10 \mathrm{~cm}$. Polychaetes were diverse; both tubiculous and burrowing types were numerous and observed to depths of $>5 \mathrm{~cm}$. Other macrofaunal constituents included ophiuroids, irregular echinoids and bivalves. For further information about the macrofaunal composition in Oslofjord, consult Mirza \& Gray (1981) and references therein. Salinity and temperature, which were monitored continuously, were similar for each mesocosm (Table 1). In the experimental mesocosm, the lowest oxygen concentration obtained was $0.16 \mathrm{ml} \mathrm{l}^{-1}$ (i.e. $<0.2 \mathrm{ml} \mathrm{l}^{-1}$ ) in February. Total organic carbon values did not show any vertical trends and ranged from 2.6 to $3.1 \%$ in the control and from 2.9 to $3.1 \%$ in the experiment box core, but was typically around $2.9 \%$ in both cores. Water content decreased from $77 \%$ and $73 \%$ in the surface $\mathrm{cm}$ to $63 \%$ and $67 \%$ between 3 and $4 \mathrm{~cm}$ in the control and experiment box cores, respectively.

\section{Assemblages in oxygenated sediments}

The macrofaunal composition in the control (continuously aerated) box core altered somewhat during the experiment. With higher dissolved-oxygen concentrations compared to the ambient levels at the sampling site, the polychaete lawn degraded. However, tall sabellid polychaetes (Hormothoe sarsii) continued to live in this mesocosm, although less densely than the original lawn of shorter spionid polychaetes.

Very few live specimens were found in either mesocosm, as determined by ATP assay. Consequently, the numerical density data resulting from the ATP analyses are not presented, but, the data can be interpreted with caution on a presence/absence basis (Table 3). At

Table 3. Occurrence of live foraminifera (determined by ATP assay) in control and experimental subcores. Bold type indicates $\geq 5$ live specimens of that species were extracted in that interval; italic type $=2$ to 4 live specimens of that species; regular type $=$ 1 live specimen of that species. Species key: Adg = Adercotryma glomeratum; $\mathrm{Ag}=$ Astrononion gallowayi; $\mathrm{Am}=$ Ammodiscus sp.; $\mathrm{Bp}=$ Bolivinellina pseudopunctata $\mathrm{Bs}=$ Brizalina spathulata $; \mathrm{Bm}=$ Bulimina marginata $; \mathrm{Cg}=$ Crithionina goesi Ck $=$ Cribrostomoides kosterensis; $\mathrm{Cl}=$ Cassidulina laevigata $; \mathrm{Cs}=$ Cibicides sp $;$ Ee = Elphidium excavatum; Es = Eggerelloides scabrus; $\mathrm{Ev}=$ Epistominella vitrea $; \mathrm{Ga}=$ Globobulimina auriculata $; \mathrm{Hb}=$ Haplophragmoides bradyi; $\mathrm{Hp}=$ Hippocrepina pusilla $; \mathrm{Lc}=$ Leptohalysis catella; $\mathrm{Lg}=$ L. gracilis; $\mathrm{Ma}=$ Miliammina arenacea $; \mathrm{Nl}=$ Nonionellina labradorica, $\mathrm{Ns}=\mathrm{Nonionellina} \mathrm{sp}$. $\mathrm{Nt}=\mathrm{Non}-$ ionellina turgida $; \mathrm{Pb}=$ Psammophaera bowmanni $\mathrm{Pw}=$ Pyrgo williamsoni; $\mathrm{Rs}=$ Reophax subfusiformis $; \mathrm{Rt}=$ Recurvoides trochamminiforme; $\mathrm{Sf}=$ Stainforthia fusiformis $\mathrm{Tg}=$ Textularia gracillima; $\mathrm{Tt}=T$. tenuissima; $\mathrm{Tx}=$ Trochammina $\mathrm{sp} . ; \mathrm{Tk}=$ Technitella sp. -: no live specimens; nd: no data

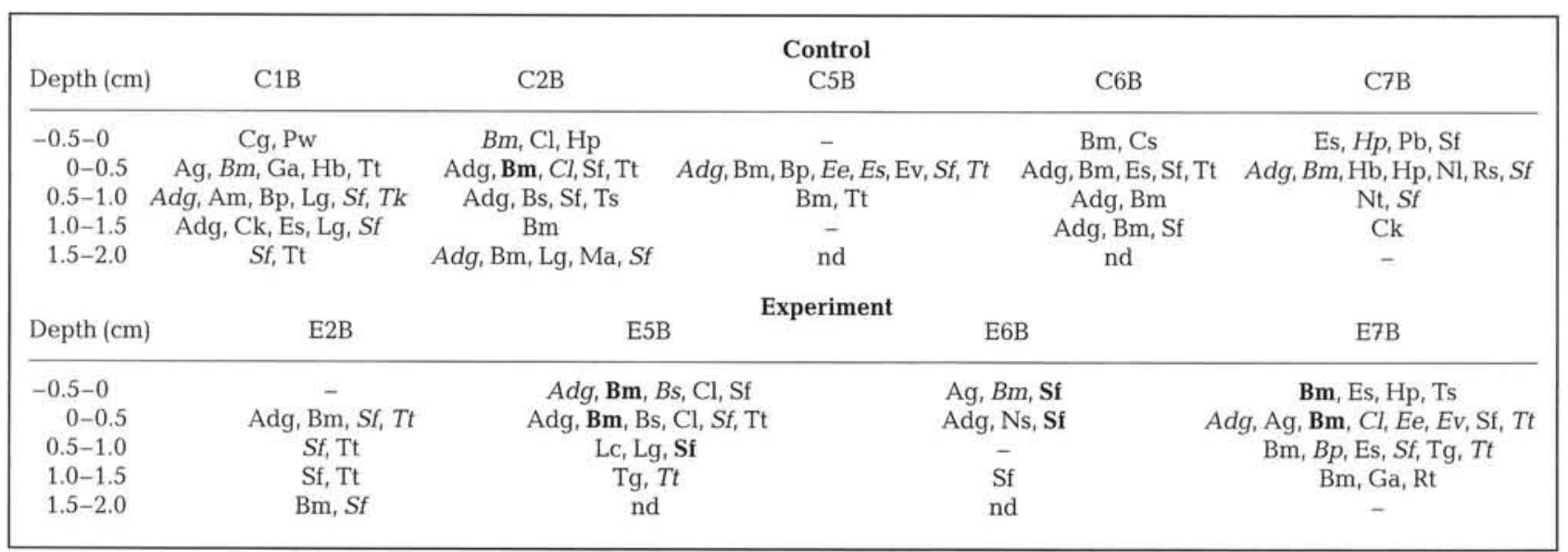


the beginning of the experiment, maximum abundances of both stained and live foraminifera occurred in the surface $0.5 \mathrm{~cm}$ of both mesocosms, although stained specimens were present throughout the top $4 \mathrm{~cm}$ (Fig. 3) and living specimens occurred to $2 \mathrm{~cm}$ depth (i.e. the maximum depth investigated with the ATP method). Approximately one-third (31 to $39 \%$ ) of the stained specimens, summed over the top $4 \mathrm{~cm}$, were found shallower than $0.5 \mathrm{~cm}$ sediment depth. These values include the rare occurrences of foraminifera on the polychaete tubes, where densities averaged $2.3 \%$ of the total stained assemblage.

Over time, the foraminiferal vertical distribution within the control box core remained relatively static, with specimens shallower than $0.5 \mathrm{~cm}$ accounting for 39 to $47 \%$ of the total stained assemblage (Fig. 4). Occurrences on the polychaete tubes averaged 1.0 stained specimen $\mathrm{cm}^{-3}$, which corresponds to $1.6 \%$ of the total stained assemblage. Stained specimens were found to the maximum depth investigated $(4 \mathrm{~cm})$ and live specimens were generally found throughout the top $2 \mathrm{~cm}$ (an exception was C5B where live specimens were found only to $1 \mathrm{~cm}$; Table 3 ). The absence of live specimens in the 100 specimens extracted per interval is not surprising since the proportion of stained specimens from 1 to $4 \mathrm{~cm}$ was less than $4 \%$ of the total (stained + unstained) assemblages and the proportion of live specimens must be considerably lower than that value. Of course, the absence of a live specimen in any given core interval may only indicate that live specimens were not included in the 100 specimens extracted.

Stained foraminiferal numerical densities in the experimental box core were always higher than those of the control, with only 1 exception (Table 2). However, while the average of the sum of stained foraminiferal densities over the top $4 \mathrm{~cm}$ in the experimental subcores was approximately twice as high as that in the control $(x=110.3, \mathrm{SD}=74.3 ; x=60.4$, $\mathrm{SD}=12.2$, respectively), there was no statistically significant difference between these 2 sets of data (Smirnov 2-sample test, $\mathrm{p}>0.05$; Conover 1971).

\section{Responses of the experimental box core assemblages}

After exposure to $4 \mathrm{wk}$ of oxygen levels at $\sim 1.3 \mathrm{ml} \mathrm{l}^{-1}$, some macrofaunal organisms were visibly affected. Some of the spionid polychaetes died, resulting in a deterioration of the polychaete lawn. Ophiuroids and echinoids remained active. After a 1 mo exposure to $0.7 \mathrm{ml} \mathrm{O}_{2} \mathrm{1}^{-1}$, the irregular echinoids were epifaunal and only 1 active ophiuroid was observed. However, burrowing polychaetes were seen to depths of at least $3 \mathrm{~cm}$. After a $2.5 \mathrm{wk}$ exposure to $<0.2 \mathrm{ml} \mathrm{O}_{2} \mathrm{l}^{-1}$, all echinoids were dead, live ophiuroids were not observed, and the dead spionid polychaete bodies were protruding from the tops of their tubes. At this time, polychaetes that normally burrow were partially or completely extended above the sediment-water inter-
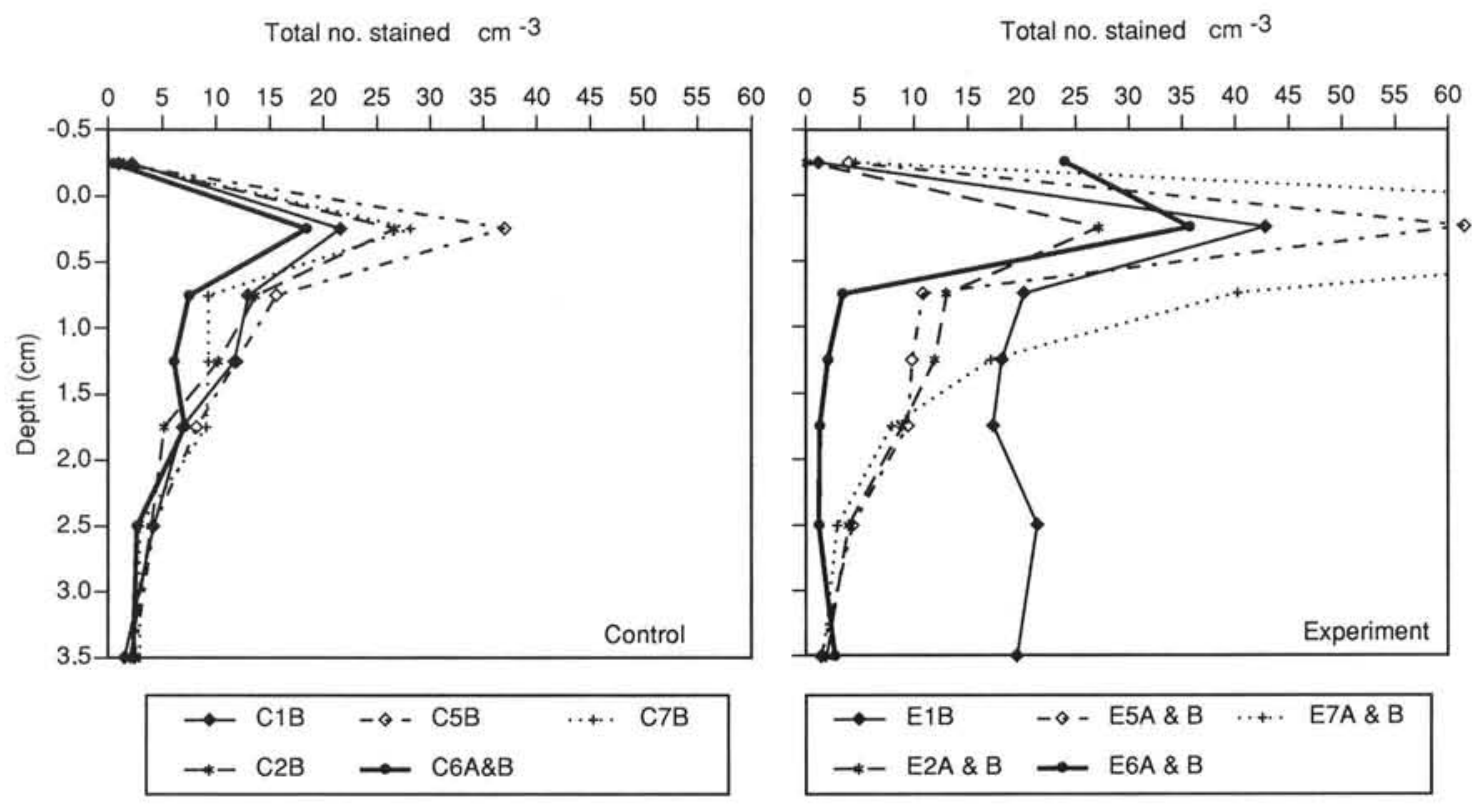

Fig. 3. Down-core foraminiferal numerical densities for the control ( $C$; left) and experimental (E; right) mesocosms. Note that some traces represent the average for the 2 replicate subcores (A \& B) taken in that mesocosm for that sampling event (1 to 7 , corresponding to events listed in Table 1). The off-scale value for E7A \& B, 0 to $0.5 \mathrm{~cm}$, is $116 \mathrm{specimens}^{-3}$. The interval -0.5 to $0 \mathrm{~cm}$ represents densities on the polychaete tubes extending above the sediment-water interface 

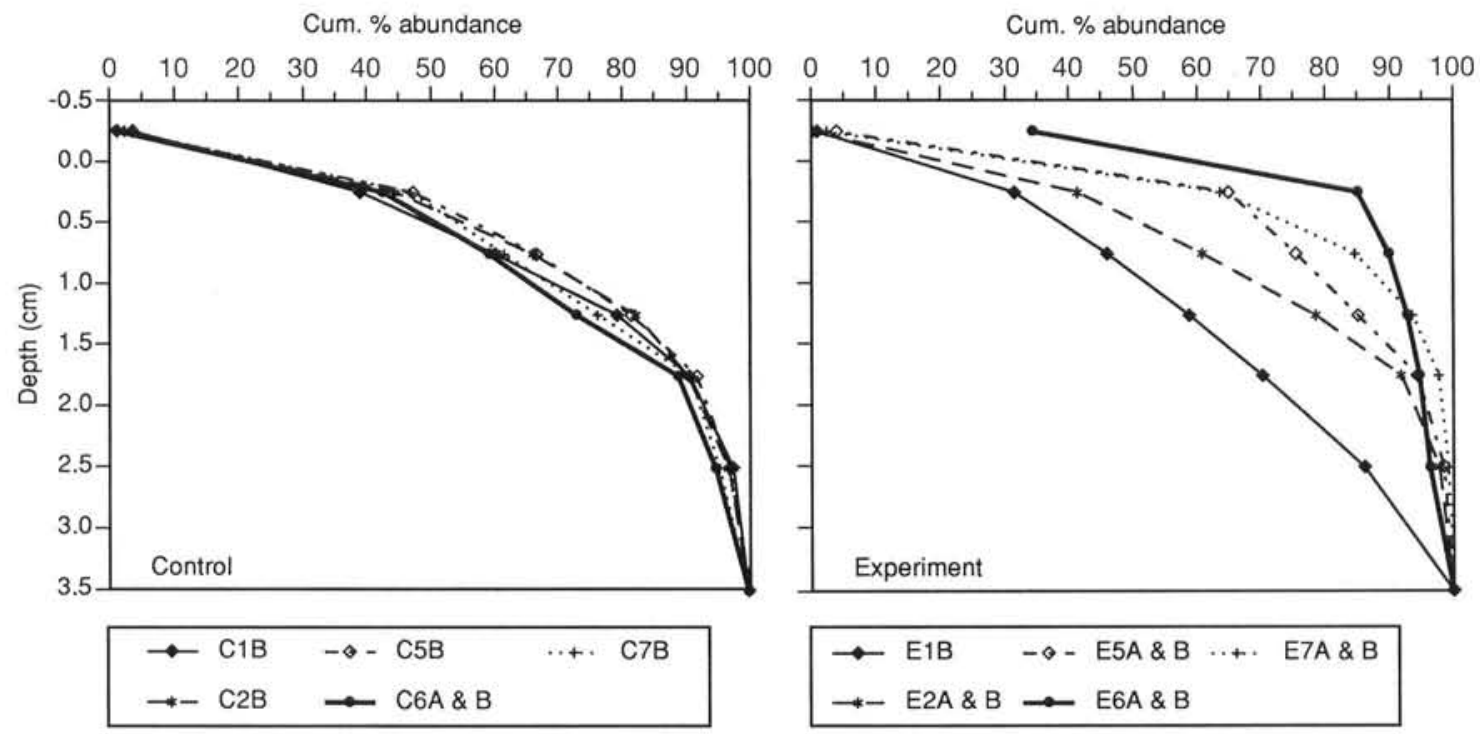

Fig. 4. As in Fig. 3 but showing down-core cumulative percent of stained foraminifera for each mesocosm over the course of the experiment

face or climbing the walls of the mesocosm. After another $2.5 \mathrm{wk}$ exposure to oxygen levels of $<0.2 \mathrm{ml}$ $1^{-1}$, all macrofauna were dead except 1 polychaete, which had crawled onto the mesocosm wall to a position approximately $10 \mathrm{~cm}$ above the sediment-water interface. Most of the empty polychaete tubes, while extremely fragile, remained extended above the sediment-seawater interface. After re-aeration for $4 \mathrm{mo}$, greyish fecal pellets were present on the sediment surface but macrofauna were not visible. The sediments of the surface centimeter were slightly orange in color and distinctly stratified, indicating a lack of bioturbation.

As oxygen concentrations decreased throughout the experiment, the foraminiferal distribution became more concentrated within the surface $0.5 \mathrm{~cm}$ and onto the portion of polychaete tubes which extended above the sediment-water interface (schematically shown in Fig. 5). By sampling event 5 (after a 2.5 wk exposure to $<0.2 \mathrm{ml} \mathrm{O}_{2} \mathrm{l}^{-1}$ ), over half ( 53 to $70 \%$ ) of the stained foraminifera occurred shallower than $0.5 \mathrm{~cm}$ depth. Live and stained specimens also occurred in higher abundances on the polychaete tubes $(\sim 4$ stained specimens $\mathrm{cm}^{-3}$ ). After a $5 \mathrm{wk}$ exposure to $<0.2 \mathrm{ml} \mathrm{O}_{2}$ $1^{-1}$ (sampling event 6), 80 to $90 \%$ of the stained foraminifera were shallower than $0.5 \mathrm{~cm}$ and only 1 live specimen was found deeper than $0.5 \mathrm{~cm}$ (Table 3). At this time, a notable increase of the foraminiferal abundance on polychaete tubes occurred. The average density (24 stained specimens $\mathrm{cm}^{-3}$ ) on tubes was 48 times higher than that in the control $(0.5$ stained specimens $\mathrm{cm}^{-3}$ ). This foraminiferal density on polychaete tubes in the experimental mesocosm is equiva- lent to $34 \%$ of the total stained assemblage (Fig. 4). At sampling event 6 , the number of species found stained on polychaete tubes was 16 to 18 compared to 8 at sampling event 1.

After re-oxygenation for $4 \mathrm{mo}$, the proportion of stained foraminifera in the surface $0.5 \mathrm{~cm}$ declined to $\sim 44$ to $70 \%$ and stained specimens were found throughout the top $4 \mathrm{~cm}$. A concomitant decrease in

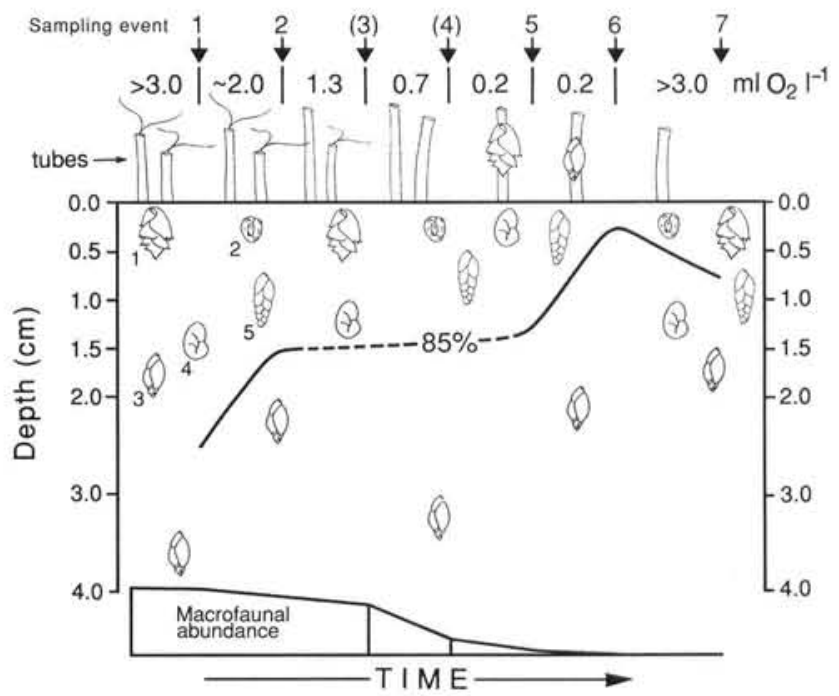

Fig. 5. Schematic representation of foraminiferal vertical distributions over time and the relative estimated macrofaunal abundance in the experimental mesocosm. The $85 \%$ horizon indicates the level above which $85 \%$ of the stained individuals occurred. Species key: 1 = Bulimina marginata, 2 = Adercotryma glomeratum, 3 = Stainforthia fusiformis, $4=$ Nonionellina labradorica, 5 = Bolivinellina pseudopunctata 
stained foraminiferal abundance on the polychaete tubes occurred, but values remained higher than those of the control box core ( 3.3 to 6.0 stained specimens $\mathrm{cm}^{-3}$ ). However, the proportions of stained foraminifera on the polychaete tubes ( 2.1 to $3.9 \%$ ) were comparable to those of the control box core. At this time, live specimens were found to $1.5 \mathrm{~cm}$ depth. The number of species that were found stained on the polychaete tubes had decreased to 10 or 11 .

\section{Species response}

The dominant foraminiferal species were Bulimina marginata and Stainforthia fusiformis. Other taxa comprising $>5 \%$ of the stained assemblage in 10 or more samples were Nonionellina labradorica, Nonionella turgida, Adercotryma glomeratum, Bolivinellina pseudopunctata, Nonionella spp., Epistominella vitrea, Globobulimina auriculata, and Brizalina spathulata. Of these species, only A. glomeratum is agglutinated; all others are calcareous.

In the control mesocosm, Bulimina marginata consistently exhibited maximum abundances in the surface $0.5 \mathrm{~cm}$ of sediment, but rarely occurred on polychaete tubes (Fig. 6). Live specimens were found to depths of $2 \mathrm{~cm}$ near the beginning of the experiment ( $\mathrm{C} 2 \mathrm{~B}$ \& E2B, Table 3). Over the course of the experimental decrease in oxygen, B. marginata densities increased substantially on the polychaete tubes until, during sampling event 6, live specimens were found only on polychaete tubes. After re-oxygenation, stained $B$. marginata continued to occur on the polychaete tubes, but in considerably lower abundances and live specimens were found to depths of $1.5 \mathrm{~cm}$. In all sampling events for both mesocosms, the majority of the stained B. marginata were juveniles.

In the control core, stained Stainforthia fusiformis exhibited subsurface maximum abundances between 0.5 and $2.0 \mathrm{~cm}$ (Fig. 6). Live specimens were found to $2 \mathrm{~cm}$ depth and only 1 live specimen was ever found on the polychaete tubes. In the experimental mesocosm, $S$. fusiformis exhibited similar distributions except after exposure to $<0.2 \mathrm{ml} \mathrm{O}_{2} \mathrm{l}^{-1}$ (sampling events 5 and 6), when maximum abundances were shallower than $0.5 \mathrm{~cm}$ and live specimens were rarely found deeper than $1.0 \mathrm{~cm}$. In these subcores, live specimens were found on the polychaete tubes, often in high numbers. In 1 instance, the maximum numerical density of stained $S$. fusiformis was on the polychaete tubes (E6B). After re-oxygenation, $S$. fusiformis maximum abundances occurred deeper than $0.5 \mathrm{~cm}$ and this species rarely remained on the polychaete tubes.

Nonionellina labradorica consistently exhibited subsurface maxima between 1.0 and $2.0 \mathrm{~cm}$ in the control (except for 1 subcore where the maximum was between 0.5 and $1.5 \mathrm{~cm}$ ) and for the first 2 sampling events in the experimental mesocosm (Fig. 6). By sampling event $5, N$. labradorica maximum abundance shoaled to 0.5 to $1.0 \mathrm{~cm}$ in the experimental box core. By sampling event 6 (after a $5 \mathrm{wk}$ exposure to $<0.2 \mathrm{ml}$ $\mathrm{O}_{2} \mathrm{l}^{-1}$ ), the maximum abundance for this species was in the surface $0.5 \mathrm{~cm}$. After re-oxygenation, the $N$. labradorica maximum occurred between 0.5 and $1.0 \mathrm{~cm}$. N. labradorica (live, stained or unstained) were never found on polychaete tubes. Throughout the experiment, Nonionella turgida exhibited similar vertical distributions and responses as $N$. labradorica.

At the beginning of the experiment, stained Bolivinellina pseudopunctata were found throughout the top $4 \mathrm{~cm}$, but not on polychaete tubes (Fig. 6). The maximum abundance of stained $B$. pseudopunctata was between 0.5 and $1.0 \mathrm{~cm}$ in both mesocosms. As the experiment progressed, considerably higher proportions of stained specimens were found on the polychaete tubes. Indeed, for both experimental subcores collected during event 6 , the stained numerical density on the polychaete tubes exceeded that in the surface $0.5 \mathrm{~cm}$. After re-oxygenation, only a few specimens remained on the tubes and the subsurface maximum was re-established.

Adercotryma glomeratum always exhibited maximum stained abundances in the top $0.5 \mathrm{~cm}$ (the average for both mesocosms for the entire experiment $=3.9$ specimens $\left.\mathrm{cm}^{-3}, \mathrm{SD}=4.6\right)$. Near the beginning of the experiment (C2B), A. glomeratum was found live to $2.0 \mathrm{~cm}$ depth and stained in moderate abundance $\left(x=0.7 \mathrm{~cm}^{-3}\right.$, $\mathrm{SD}=0.4$ ) between 0.5 and $4.0 \mathrm{~cm}$. However, over the course of the experiment, $A$. glomeratum was not found living deeper than $0.5 \mathrm{~cm}$ and stained specimens only rarely occurred deeper than $0.5 \mathrm{~cm}$. After reoxygenation, stained A. glomeratum consistently occurred throughout the top $4 \mathrm{~cm}$ while continuing to exhibit a maximum abundance in the superficial layer.

Stained Brizalina spathulata were found to depths of $4 \mathrm{~cm}$ but maximum abundances were always in the surface $0.5 \mathrm{~cm}$. As the experiment progressed, increasing proportions of stained specimens were found on the polychaete tubes. After re-oxygenation, few specimens remained upon the tubes.

At the beginning of the experiment, stained Globobulimina auriculata were found throughout the top $4 \mathrm{~cm}$, but only rarely occurred in the surface 0.5 to $1.0 \mathrm{~cm}$. As the experiment proceeded, this species migrated upward, and was present only in the upper $0.5 \mathrm{~cm}$ at sampling event 6 . G. auriculata was never found on the polychaete tubes. After re-oxygenation, the maximum of this species was deeper than $0.5 \mathrm{~cm}$.

Epistominella vitrea did not exhibit a consistent depth occurrence over time in the control mesocosm 
CONTROL
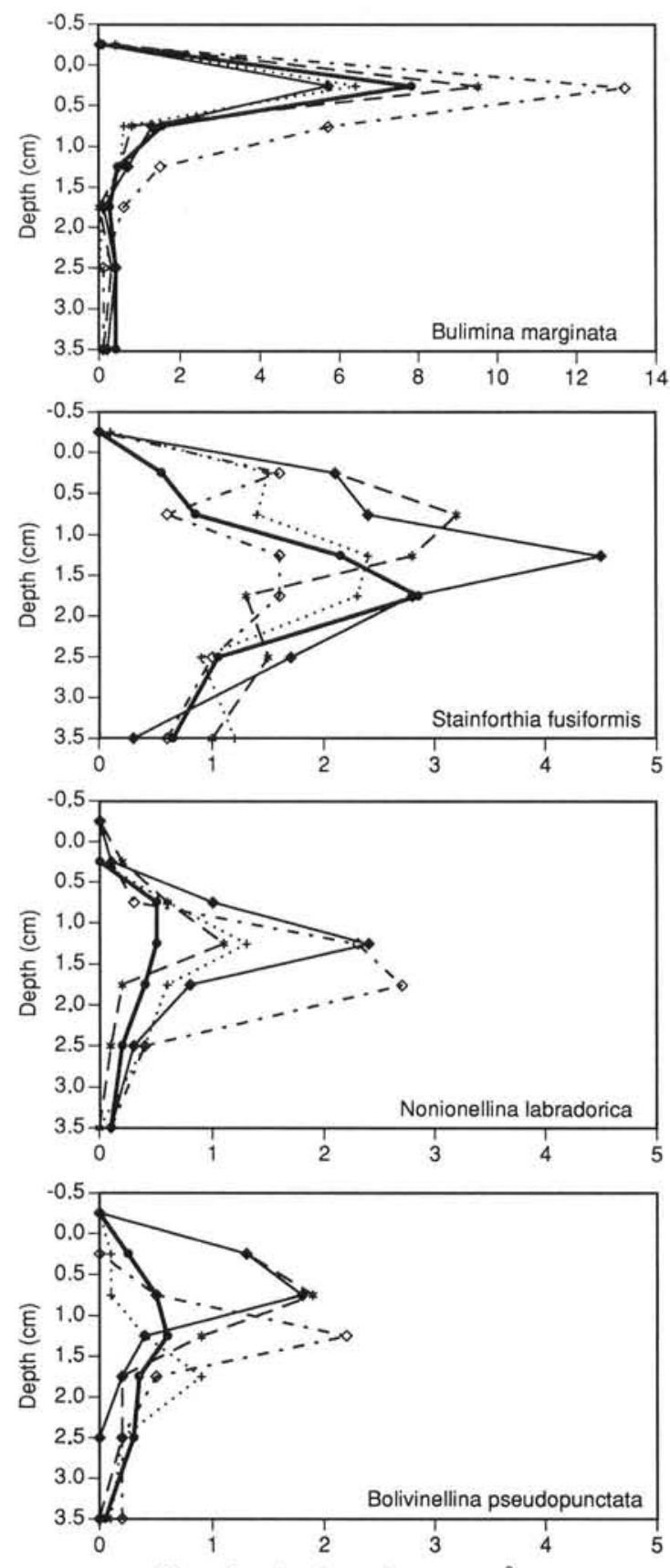

No. of stained specimens $\mathrm{cm}^{-3}$

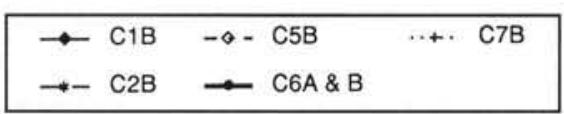

EXPERIMENT
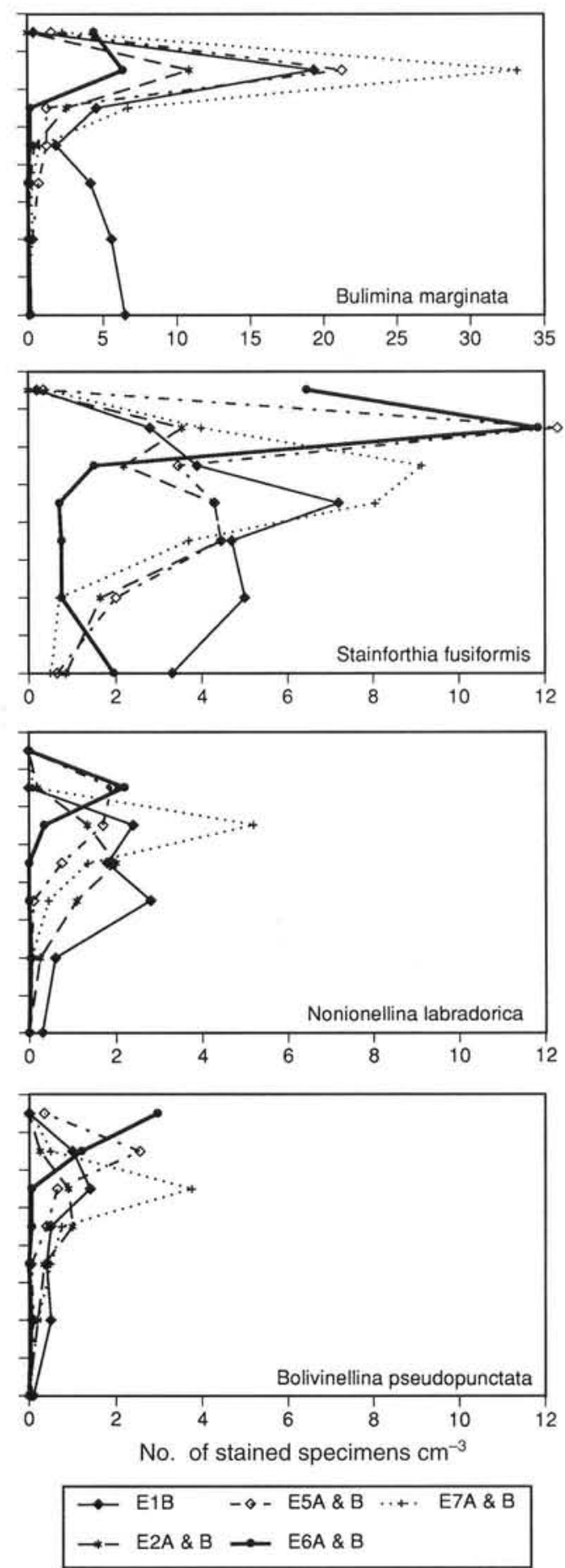

Fig. 6. Down-core numerical densities of stained specimens for the 4 most common species for the control and experimental mesocosms. Note the differences in the abscissa scales

but was found with maximum abundance between 3 and $4 \mathrm{~cm}$ depth at sampling event 1 in the experimental mesocosm. Subsequently, this species was only rarely found that deep in the sediments, and maximum abundances occurred in the surface $0.5 \mathrm{~cm}$. Stained specimens were found on the polychaete tubes only after exposure to $5 \mathrm{wk}$ of $<0.2 \mathrm{ml} \mathrm{O}_{2} \mathrm{l}^{-1}$. Some specimens remained on the tubes after re-oxygenation. 
Pyrgo williamsoni was never abundant and comprised $>5 \%$ of the stained assemblage in only 1 instance $(6 \%$ in $\mathrm{E} 2 \mathrm{~A}, 0.5$ to $1.0 \mathrm{~cm})$. However, during exposure to $<0.2 \mathrm{ml} \mathrm{O}_{2} \mathrm{l}^{-1}$ (sampling events 5 and 6), an increasing number of this conspicuous, large (up to $0.9 \mathrm{~mm}$ ), white species was observed on the sediment surface and on polychaete tubes.

Crithionina goesi and Hippocrepina pusilla were usually found living attached to the polychaete tubes and were only occasionally found stained in sediments. Of course, H. pusilla, a thin-shelled agglutinated species, generally does not remain intact through sediment processing. When found on a polychaete tube, $H$. pusilla was usually covered with a layer of detritus which partially obscured the specimen from view. Other species found stained on the polychaete tubes, besides those previously noted, include the calcareous Cibicides sp., Cassidulina laevigata, and Astrononion gallowayi and the agglutinated Recurvoides trochamminiforme, Textularia spp., and Leptohalysis spp. Live C. laevigata and A. gallowayi were also found in the surface $0.5 \mathrm{~cm}$ of sediment.

Many specimens of certain species (Astrononion gallowayi, Bolivinellina pseudopunctata, Elphidium excavatum, Epistominella vitrea, Globobulimina auriculata, Nonionella turgida, Nonionellina labradorica, and Stainforthia fusiformis) had a yellowish-light green color in their older chambers (where the rose Bengal stain did not penetrate). All these species showed maximum abundances below the upper $0.5 \mathrm{~cm}$ at all sampling events, except during the period of maximum oxygen depletion in the experimental mesocosm. The coloration in specimens recovered from later sampling events was pale compared to that of specimens collected early in the experiment. On the other hand, yellow-green coloration did not occur in Bulimina marginata, Brizalina spathulata, Cassidulina laevigata or Hyalinea balthica, which always showed maximum abundances shallower than $0.5 \mathrm{~cm}$.

\section{DISCUSSION}

\section{Methodology}

While it has been argued that ATP analysis is a more reliable method than rose Bengal to determine foraminiferal numerical densities (Bernhard 1988), rose Bengal is also reported to be an accurate and reliable method (Lutze \& Altenbach 1991). In instances where there are high proportions of empty tests and dead specimens (i.e. this study), we conclude that rose Bengal is more reliable than the ATP method to determine foraminiferal numerical densities since the former method is not time dependent (e.g. samples are preserved) permitting examination of more specimens. Another reason why the rose Bengal method produced acceptable results in our study may involve the rate of autolysis at atmospheric pressure. Autolysis is a complex process and its response to hydrostatic pressure is unpredictable (e.g. Jaenicke 1981), but it is possible that foraminiferal autolysis at atmospheric pressure (i.e. our samples) occurred more rapidly than it would have occurred at ambient pressure (i.e. at $71 \mathrm{~m}$ water depth). Consequently, the postmortem existence of foraminiferal cytoplasm may have been shorter in our mesocosms than one would normally expect in situ. To support this possibility is the estimated prolonged persistence of dead foraminiferal cytoplasm in the deep sea (i.e. months to years; Corliss \& Emerson 1990). Therefore, rose Bengal should only be used with caution for routine numerical density determinations, especially for samples collected from environments with high hydrostatic pressure. Analysis of ATP remains the method of choice for biomass determinations (e.g. DeLaca 1986, Bernhard 1992).

\section{Assemblage response}

In the experimental mesocosm, where virtually all macrofauna died during the study, the foraminiferal populations survived and migrated upward when dissolved oxygen levels were decreased. Our results confirm that at least some foraminifera are less sensitive to hypoxia than metazoans (Josefson \& Widbom 1988) and therefore are well adapted to survive seasonal or episodic events of oxygen depletion associated with, for instance, eutrophication. In addition to the upward migration, and possibly more interestingly, the foraminifera migrated back down into the sediments once the mesocosm was re-oxygenated. In contrast, the foraminiferal distribution in the control (i.e. continually aerated) mesocosm remained relatively static over the 8 mo experiment, illustrating the ability of microhabitat-selective species to remain in their optimal position over time regardless of bioturbation activity. These findings do not support Moodley's (1990) conclusion that foraminiferal vertical distribution in the sediments primarily are governed by the burrowing activities of macrofauna.

Foraminiferal abundances on the polychaete tubes in the control box core were always low, while abundances on the decaying polychaete tubes of the experimental box core became surprisingly high during the period of lowest oxygen concentrations. In fact, in 1 case (E6B) the stained foraminiferal abundance on the tubes exceeded that in the surface $0.5 \mathrm{~cm}$.

It is well established that most benthic foraminifera are mobile and they may move at rates which ap- 
proach $100 \mu \mathrm{m} \mathrm{min}{ }^{-1}$ (Kitazato 1988). The impetus for movement is varied: foraminifera migrate through sediments as a response to burial (e.g. Severin \& Erskian 1981), throughout their life cycle (Matera \& Lee 1972), to different habitats for food acquisition and/or changing environmental conditions (e.g. Linke \& Lutze 1993), or, as in the present study, in response to chemical gradients. The most commonly proposed reason for benthic foraminiferal occurrence above the sediment-water interface is suspension feeding (e.g. Alexander \& DeLaca 1987, Linke 1992, Altenbach et al. 1993, Linke \& Lutze 1993) and polychaete tubes are among the various substrates that foraminifera use for elevation above the interface (Kitazato 1989, Mackensen \& Douglas 1989, Linke \& Lutze 1993). In our experiment, the foraminifera are probably not migrating up the polychaete tubes in order to suspension feed. If this were the case, the foraminifera would have been situated on the tubes at the beginning of the experiment and they would not have re-entered the sediments after re-oxygenation. While it is likely that some foraminifera optimize their food acquisition by migrating from one microhabitat to another which possesses greater food availability (Linke \& Lutze 1993), it is also known that certain infaunal foraminifera do not migrate upward as a response to episodic food inputs (i.e. phytodetritus; Gooday \& Turley 1990). It is possible that the foraminifera on the tubes were taking advantage of a plentiful food source (i.e. the dead polychaetes), as observed for the large, carnivorous agglutinated antarctic foraminifer Astrammina rara (S. S. Bowser \& J. M. Bernhard pers. obs.), but this possibility is unlikely since the foraminifera in the control mesocosm did not migrate onto the polychaete tubes to feed on the dead polychaetes in that mesocosm. Our preferred explanation is that the foraminifera situated themselves above the sediment-water interface in the experimental mesocosm to gain exposure to higher oxygen levels. In fact, qualitative observations by Linke \& Lutze (1993) support our explanation. They observed that the number of foraminifera visible on the sediment surface increased dramatically after the sediment surface of cores was colonized by sulfideoxidizing bacteria. In addition, some foraminifera were seen on polychaete tubes. While oxygen data was not obtained, their speculation was that the foraminifera migrated as a response to anoxic conditions.

It is generally accepted that foraminifera are obligate aerobes and some species have higher than expected respiration rates (Hannah et al. 1994). However, the pioneering laboratory work of Bradshaw (1961) showed that at least some foraminiferal species require very little oxygen to survive. Recent experimental studies conclude that certain benthic foraminifera may be facultative anaerobes for moderate periods of time
(Moodley \& Hess 1992, Bernhard 1993) and field studies support this conclusion (Bernhard \& Reimers 1991, Sen Gupta \& Machain-Castillo 1993, Alve 1994). The fact that, in this study, the maximum abundance of certain species was deeper than others provides additional evidence that some species require less oxygen than others, and possibly do not require any oxygen, to survive (e.g. Stainforthia fusiformis vs Bulimina marginata; see below).

The question remains why the foraminifera returned to the sediments after re-oxygenation, since another commonly accepted notion of foraminiferal biology, seemingly contradictory to our results, is that they are negatively geotactic (e.g. Lee \& Faber 1992). Indeed, downward foraminiferal migration has only rarely been documented (in response to increased flow regimes; Palmer \& Molloy 1986) even though infaunal foraminiferal distributions are universally recognized, as previously discussed. One commonly proposed reason to explain why foraminifera are infaunal is to avoid predation pressure from macroepifauna (e.g. Gooday 1986, Mackensen \& Douglas 1989). However, in our experimental treatment, predation pressure surely was minimal during reoxygenation of the mesocosm, as nearly all macrofauna had died. Still, the foraminifera returned down into the sediments. Our conclusion that foraminiferal species select different optimal oxygen regimes and their associated biochemical microenvironments helps to explain foraminiferal downward migration. While oxygen levels were not measured directly within the sediments, it appears that species tracked a particular oxygen regime, regardless of its depth in the sediment column, since foraminifera responded to increased as well as decreased oxygen concentrations. The fact that the distribution in the experimental mesocosm did not completely return to its initial pattern even after $4 \mathrm{mo}$ of re-aeration (Fig. 4) may be because macrofauna were not present to bioturbate, and consequently re-aerate, the sediments as deeply as at the initiation of the experiment.

\section{Species response}

The common species exhibited 2 major distributional and response patterns to the varying oxygen concentrations. Species such as Bulimina marginata, Adercotryma glomeratum, and Brizalina spathulata consistently exhibited maximum abundances in the surface $0.5 \mathrm{~cm}$ or on the polychaete tubes irrespective of the degree of oxygenation. The second distributional and response pattern was exhibited by most other species. Stainforthia fusiformis, Nonionellina labradorica, Nonionella turgida, Bolivinellina pseudopunctata, Globobulimina auriculata, and Epistominella vitrea all 
exhibited subsurface $(>0.5 \mathrm{~cm})$ maximum occurrences before exposure to dysaerobic conditions. While dysaerobic conditions were maintained, these species migrated upward, exhibiting maximum abundances either in the surface $0.5 \mathrm{~cm}$ of sediment or upon the polychaete tubes. However, Nonionellina labradorica, Nonionella turgida, and G. auriculata were never found on polychaete tubes. After re-oxygenation, the species which originally exhibited subsurface maximum abundances returned to primarily infaunal distributions, although some specimens remained upon the polychaete tubes.

Bulimina marginata was consistently the dominant species shallower than $0.5 \mathrm{~cm}$ and occasionally dominant between 0.5 and $1.0 \mathrm{~cm}$, whereas Stainforthia fusiformis was dominant deeper than $1 \mathrm{~cm}$ for all sampling events in the control mesocosm (except 1 where $S$. fusiformis had unusually low abundances). This pattern was also observed in the experimental mesocosm for sampling events 1, 2, and 7. These observations demonstrate the consistency in microhabitat separation between these 2 species on both intra- and inter-mesocosm scales.

Stainforthia fusiformis is a typical opportunist, being the first foraminifera to recolonize organic-rich, formerly anoxic fjord sediments (Alve 1990), where it survives brief periods of anoxia (Alve 1994). This is probably why $S$. fusiformis was the predominant infaunal species throughout our study. However, S. fusiformis is also known to dominate surface sediments $(0$ to $1 \mathrm{~cm})$ in well-oxygenated areas of the North Sea (as Fursenkoina fusiformis in Murray 1985, 1992). These seemingly contradictory observations demonstrate that at least some species are capable of exploiting a variety of microhabitats, an important observation with both ecological and paleoecological implications.

Bulimina marginata also exhibits opportunistic traits. The observation that the majority of $B$. marginata were juveniles indicates that this species reproduced continuously at least from October through June. During sampling events 1,2 , and 7 in the experimental mesocosm, the total absolute abundance of $B$. marginata, summed over the top $4 \mathrm{~cm}$, was consistently higher than that of Stainforthia fusiformis. Hence, one may expect $B$. marginata to dominate even after the maximum upward migration of infaunal specimens (sampling event 6). However, at this time, B. marginata was outnumbered in the upper $0.5 \mathrm{~cm}$ by S. fusiformis (Fig. 5). This suggests that even though $S$. fusiformis also migrated upward towards more oxygenated conditions, it was less affected by the low oxygen concentrations than $B$. marginata and therefore reproduced more rapidly. After re-oxygenation, B. marginata flourished in the surface sediment layer $(0.5 \mathrm{~cm})$.
It has been suggested that the apertural canal in some Bulimina species regulates oxygen concentration in the intratest cytoplasm of specimens found in dysaerobic sediments (Verhallen 1986). If this were the case, B. marginata is expected to remain in oxygendepleted sediments. However, our results indicate that this species migrated as far as possible into more oxygenated waters above the sediment-water interface. It is unlikely, therefore, that the function of the apertural canal is to channel oxygen into the cytoplasm of B. marginata.

It is likely that organic carbon content (i.e. food availability) also plays an important role in determining vertical distributions of foraminifera. For obligate aerobes, as long as the pore-water oxygen concentration is above a certain threshold, potentially infaunal species will populate those sediments, probably to take advantage of available food and to avoid competition with epifauna (Gooday 1986). The infaunal species exhibiting a yellow-green coloring presumably exploit algae as a nutrient source. While it is likely that the algae are used for food by some species, at least 2 of the colored species, Nonionellina labradorica and Stainforthia fusiformis, retain viable chloroplasts in their cytoplasm, possibly as symbionts (Cedhagen 1991). In order for the infaunal foraminifera to acquire algae, either the foraminifera must migrate to the sediment-water interface, the algae must be bioturbated into the sediments, or the foraminiferal pseudopods sequester the algae near the sedimentwater interface and transport them to the infaunal test. The latter 2 possibilities are more likely than the former since species with green coloration only rarely occurred in superficial sediments of the control. Bioturbation is known to mix algae quickly into sediments, where the concentrations of chloroplastic pigment equivalents (CPE) at sediment depths of 1 to $3 \mathrm{~cm}$ can be higher at certain times of the year than CPE concentrations at 0 to $1 \mathrm{~cm}$ (Faubel et al. 1983, see also Graf 1989). The fact that foraminifera at the end of the experiment were pale and that they migrated into the sediments after re-aeration when bioturbators, and consequently fresh algal material, were absent from the sediments indicates that these foraminifera must also utilize other nutrient sources. While the organic carbon content of the sediments was high $(\sim 2.9 \%)$, suggesting a plentiful food supply, some of the available material (e.g. dead infauna) may not necessarily be used by foraminifera. However, a likely food source, which foraminifera requiring little or no oxygen may exploit, is bacteria associated with rotting animals and with the redox boundary (e.g. sulfide oxidizers, iron oxidizers, nitrate reducers). The filamentous sulfideoxidizing bacteria Beggiatoa sp. has been observed in the food vacuoles of a species closely related to $N$. 
labradorica (Nonionella stella; Bernhard \& Reimers 1991) and foraminiferal feeding has been observed at the redox boundary (Linke \& Lutze 1993).

Our observations do not support the conclusion that most agglutinated foraminifera are deep-living infaunal species (Buzas et al. 1993). The only 2 common agglutinated species in our assemblage, Adercotryma glomeratum and Crithionina goesi, exhibited shallowinfaunal and epifaunal distributions, respectively.

\section{Comments on test morphology}

It has been suggested that benthic foraminiferal test characteristics vary according to microhabitat. For instance, in the deep sea, epifaunal species generally have trochospiral coiling and biconvex or planoconvex shapes, whereas more rounded shapes (e.g. planispiral and triserial coiling) are exhibited by infaunal species (Corliss 1985, 1991). In addition, pores in the test of epifaunal species commonly occur only on one side of the test while the pores of infaunal species typically occur on all parts of the test. It has also been proposed that small-sized species are more common in oxygen-depleted (i.e. infaunal) environments than well-oxygenated environments (Bernhard 1986 and references therein). Lastly, the tests of species found in oxygen-depleted environments are suggested to be characterized by thin, unornamented walls (Harman 1964). In our experiment, Stainforthia fusiformis, the most abundant species deepest in the sediments, and some of the species with subsurface maxima (e.g. Bolivina spp.) do have small, thin-walled, unornamented tests. Therefore, these species exhibit many of the test characteristics thought to be representative of opportunistic species (Gooday 1993, Alve 1994) or of deep infaunal species. However, other commonly occurring species which have distinct subsurface maxima, such as Nonionellina labradorica (trochospiralplanispiral test) and Nonionella turgida (trochospiral), exhibit test characteristics more representative of epifaunal species according to Corliss' (1991) definition. Furthermore, Bulimina marginata, the most abundant species occurring in superficial sediments (i.e. 0.0 to $0.5 \mathrm{~cm}$ ) or on the polychaete tubes, is triserial (i.e. elongated), has thicker walls, some ornamentation, and pores distributed about its test. According to the distribution of this species, it would be classified as epifaunal, using definitions of Corliss (1991). However, if we were to classify the species based on test characteristics, it would be termed shallow infaunal using Corliss' (1991) criteria. As noted by Sen Gupta \& Machian-Castillo (1993), representatives of all morphologies, sizes, degrees of ornamentation, and pore distributions can be found in nearly every microhabitat with respect to oxygen (i.e. anoxic, dysaerobic, wellaerated). Therefore, considering the highly dynamic nature of foraminiferal vertical distributions, at least in variable environmental settings, caution should be taken if these types of characteristics are used to infer environmental attributes.

\section{CONCLUSIONS}

Our results show that, at atmospheric pressure, detailed variations in the vertical distribution patterns of benthic foraminifera can be traced using rose Bengal when samples are collected over relatively short time spans (i.e. 2.5 to $4 \mathrm{wk}$ ). In the aerated control mesocosm, we observed the ability of microhabitatselective species to remain in their optimal position within the sediments over time irrespective of the activity of bioturbators. Under our experimental conditions, infaunal species started migrating upward when overlying waters decreased below $2 \mathrm{ml} \mathrm{O}_{2} \mathrm{I}^{-1}$. Some of the infaunal and surface-dwelling species emerged above the sediment-water interface (i.e. onto polychaete tubes) when oxygen concentrations dropped below $0.2 \mathrm{ml} \mathrm{l}^{-1}$. After re-oxygenation, the foraminifera actively moved downward toward their original depth distribution, although after 4 mo the maximum abundance of some species was not as deep as it was originally. These shallower vertical distributions were probably due to inadequately aerated subsurface sediments, resulting from a lack of bioturbation. Our results provide the first published quantitative experimental evidence of foraminiferal migration as a result of controlled, altered oxygen concentrations. We conclude that some foraminiferal species select an optimal oxygen regime regardless of its position with respect to the sediment-water interface. It is likely that foraminifera select a microhabitat where food supply is optimized in apposition to oxygen demand. Further experimental studies are needed to assess the response of foraminifera to manipulated organic carbon concentrations while holding oxygen concentrations constant.

Acknowledgements. We thank Are Pedersen and Per Hall for helpful discussions in the planning stages of this study. A most heartfelt 'thank you' to Einar Johannessen for his help in collecting, establishing and monitoring the experiment. We also thank the crew of the RV 'Trygve Braarud', Haakon Oen, Oddbjørn Pettersen, Jonas Gunnarson, Jens Skei, Bengt Christiansen, Hans Grav, Inger-Ann Hansen, Torbjørn Sætre, Carola Noji, Knut Bjørlykke, and Kjell Nordberg for their assistance at various stages of our study. Thanks are also due Sam Bowser, Andy Gooday, Peter Linke, and an anonymous referee for many helpful comments on the manuscript. The use of facilities at the Norwegian Institute for Water Research (NIVA) and NIVA Solbergstrand are gratefully appreciated. This study was supported by The Fulbright Foundation 
(research grant to J.M.B.), Norge-Amerika Foreningen, NSF grant OCE-9211166 to J.M.B., a Norwegian Research Council for Science and the Humanities (NAVF) grant to E.A., and NIVA project E 80400 . In memory of H.G.S.

\section{LITERATURE CITED}

Alexander, S. P., DeLaca, T. E. (1987). Feeding adaptations of the foraminiferan Cibicides refulgens living epizoically and parasitically on the antarctic scallop Adamussium colbecki. Biol. Bull. 173: 136-159

Altenbach, A. V., Heeger, T., Linke, P., Spindler, M., Thies, A. (1993). Miliolinella subrotunda (Montagu), a miliolid foraminifer building large detritic tubes for a temporary epibenthic lifestyle. Mar. Micropaleontol. 20; 293-301

Altenbach, A. V., Sarnthein, M. (1989). Productivity record in benthic foraminifera. In: Berger, W. H., Smetacek, V. S., Wefer, G. (eds.) Productivity of the ocean: present and past. John Wiley, New York, p. 255-269

Alve, E. (1990). Variations in estuarine foraminiferal biofacies with diminishing oxygen conditions in Drammensfjord, SE Norway. In: Hemleben, C., Kaminski, M. A., Kuhnt, W., Scott, D. B. (eds.) Paleoecology, biostratigraphy and taxonomy of agglutinated foraminifera. Kluwer, Dordrecht, p. 661-694

Alve, E. (1994). Opportunistic features of the foraminifer Stainforthia fusiformis (Williamson): evidence from Frierfjord, Norway. J. Micropalaeontol. 13: 24

Alve, E. (1995). Benthic foraminiferal responses to estuarine pollution: a review. J. Foram. Res. 25: in press

Barmawidjaja, D. M., Jorissen, F. J., Puskaric, S., van der Zwaan, G. J. (1992). Microhabitat selection by benthic foraminifera in the northern Adriatic Sea. J. Foram. Res. 22: $297-317$

Bernhard, J. M. (1986). Characteristic assemblages and morphologies of benthic foraminifera from anoxic, organic rich deposits: Jurassic through Holocene. J. Foram. Res. 16: $207-215$

Bernhard, J. M. (1988). Postmortem vital staining in benthic foraminifera: duration and importance in population and distributional studies. J. Foram. Res. 18: 143-146

Bernhard, J. M. (1992). Benthic foraminiferal distribution and biomass related to pore-water oxygen content: Central California Continental Slope and Rise. Deep Sea Res. 39: 585-605

Bernhard, J. M. (1993). Experimental and field evidence of Antarctic foraminiferal tolerance to anoxia and hydrogen sulfide. Mar. Micropaleontol. 20: 203-213

Bernhard, J. M., Reimers, C. E. (1991). Benthic foraminiferal population fluctuations related to anoxia: Santa Barbara Basin. Biogeochemistry 15: 127-149

Bett, B. J., Vanreusel, A., Vincx, M., Soltwedel, T., Pfannkuche, O., Lambshead, P. J. D., Gooday, A. J., Ferrero, T., Dinet, A. (1994). Sampler bias in the quantitative study of deep-sea meiobenthos. Mar. Ecol. Prog. Ser. 104: 197-203

Bradshaw, J. S. (1961). Laboratory experiments on the ecology of foraminifera. Contrib. Cushman Found. Foram. Res. 12: 87-106

Buzas, M. A., Culver, S. J., Jorissen, F. J. (1993). A statistical evaluation of the microhabitats of living (stained) infaunal benthic foraminifera. Mar. Micropaleontol. 20: 311-320

Cedhagen, T. (1991). Retention of chloroplasts and bathymetric distribution in the sublittoral foraminiferan Nonionellina labradorica. Ophelia 33: 17-30

Chandler, G. T., Shirley, T. C., Fleeger, J. W. (1988). The tom-tom corer: a new design of the Kajak corer for use in meiofauna sampling. Hydrobiologia 169: 129-134
Conover, W. J. (1971). Practical nonparametric statistics. Wiley and Sons, New York

Corliss, B. H. (1985). Microhabitats of benthic foraminifera within deep-sea sediments. Nature 314: 435-438

Corliss, B. H. (1991). Morphology and microhabitat preferences of benthic foraminifera from the northwest Atlantic Ocean. Mar. Micropaleontol. 17: 195-236

Corliss, B. H., Emerson, S. (1990). Distribution of Rose Bengal stained deep-sea benthic foraminifera from the Nova Scotian continental margin and Gulf of Maine. Deep Sea Res. 37: 381-400

Coull, B. C., Ellison, R. L., Fleeger, J. W., Higgins, R. P., Hope, W. D., Hummon, W. D., Rieger, R. M., Sterrer, W. E., Thiel, H., Tietjen, J. H. (1977). Quantitative estimates of the meiofauna from the deep sea off North Carolina, USA. Mar. Biol. 39: 233-240

DeLaca, T. E. (1986). Determination of benthic rhizopod biomass using ATP analyses. J. Foram. Res. 16: 285-292

Faubel, A., Hartwig, E., Thiel, H. (1983). On the ecology of the benthos of sublittoral sediments, Fladen Ground, North Sea. I. Meiofauna standing stock and estimation of production. 'Meteor' Forsch.-Ergebn. Reihe D 36: 35-48

Gooday, A. J. (1986). Meiofaunal foraminiferans from the bathyal Porcupine Seabight (northeast Atlantic): size structure, standing stock, taxonomic composition, species diversity and vertical distribution in the sediments. Deep Sea Res. 33: 1345-1373

Gooday, A. J. (1993). Deep-sea benthic foraminiferal species which exploit phytodetritus: characteristic features and controls on distribution. Mar. Micropaleontol. 22: $187-205$

Gooday, A. J. (1994). The biology of deep-sea foraminifera: a review of some advances and their applications in paleoceanography. Palaios 9: 14-31

Gooday, A. J., Turley, C. M. (1990). Responses by benthic organisms to inputs of organic material to the ocean floor: a review. Phil. Trans. R. Soc. Lond. A 331: 119-138

Graf, G. (1989). Benthic-pelagic coupling in a deep-sea benthic community. Nature 341: 437-439

Hannah, F., Rogerson, A., Laybourn-Parry, J. (1994). Respiration rates and biovolumes of common benthic foraminifera (Protozoa). J. mar. biol. Ass. U.K. 74: 301-312

Harman, R. A. (1964). Distribution of foraminifera in the Santa Barbara Basin, California. Micropaleontol. 10: 81-96

Hermelin, J. O. R., Shimmield, G. B. (1990). The importance of the oxygen minimum zone and sediment geochemistry in the distribution of Recent benthic foraminifera in the northwest Indian Ocean. Mar. Geol. 91: 1-29

Hurlbert, S. H. (1984). Pseudoreplication and the design of ecological field experiments. Ecol. Monogr. 54: 187-211

Jaenicke, R. (1981). Enzymes under extremes of physical conditions. A. Rev. Biophys. Bioeng. 10: 1-67

Jorissen, F. J., Barmawidjaja, D. M., Puskaric, S., van der Zwaan, G. J. (1992). Vertical distribution of benthic foraminifera in the northern Adriatic Sea: the relation with the organic flux. Mar. Micropaleontol. 19: 131-146

Josefson, A. B., Widbom, B. (1988). Differential response of benthic macrofauna and meiofauna to hypoxia in the Gullmar Fjord basin. Mar. Biol. 100: 31-40

Kaiho, K. (1991). Global changes of Paleogene aerobic/ anaerobic benthic foraminifera and deep-sea circulation. Palaeogeogr. Palaeoclimatol. Palaeoecol. 83: 65-85

Kitazato, H. (1988). Locomotion of some benthic foraminifera in and on sediments. J. Foram. Res. 18: 344-349

Kitazato, H. (1989). Vertical distribution of benthic foraminifera within sediments. Bull. Jap. Ass. Benthol. 35/36: $41-51$ 
Koutsoukos, E. A. M., Leary, P. N., Hart, M. (1990), Latest Cenomanian-earliest Turonian low-oxygen tolerant benthonic foraminifera: a case study from the Sergipe Basin (N.E. Brazil) and the western Anglo-Paris Basin (southern England). Palaeogeogr. Palaeoclimato. Palaeoecol. 77: 145-177

Lee, J. J., Faber, W. W. Jr (1992). Culture and maintenance of benthic foraminifera. In: Lee, J. J., Soldo, A. T. (eds.) Protocols in protozoology. Allen Press, Lawrence, KS, A-32.1-A-32.3

Linke, P. (1992). Metabolic adaptations of deep-sea benthic foraminifera to seasonally varying food input. Mar. Ecol. Prog. Ser. 81: 51-63

Linke, P., Lutze, G. (1993). Microhabitat preferences of benthic foraminifera - a static concept or a dynamic adaptation to optimize food acquisition? Mar. Micropaleontol. 20: 215-234

Lutze, G. F., Altenbach, A. (1991). Technik und Signifikanz der Lebendfärbung benthischer Foraminiferen mit Bengalrot. Geol. Jb. A128: 251-265

Mackensen, A., Douglas, R. G. (1989). Down-core distribution of live and dead deep-water benthic foraminifera in box cores from the Weddell Sea and the California continental borderland. Deep Sea Res. 36: 879-900

Matera, N. J., Lee, J. J. (1972). Environmental factors affecting the standing crop of foraminifera in sublittoral and psammolittoral communities of a Long Island salt marsh. Mar. Biol. 14: 89-103

McCorkle, D. C., Keigwin, L. D., Corliss, B. H., Emerson, S. R. (1990). The influence of microhabitats on the carbon isotopic composition of deep-sea benthic foraminifera. Paleoceanography 5: 161-185

Mirza, F. B., Gray, J. S. (1981). The fauna of benthic sediments from the organically enriched Oslofjord, Norway. J. exp. mar. Biol. Ecol. 54: 181-207

Moodley, L. (1990). Southern North Sea seafloor and subsurface distribution of living benthic foraminifera. Neth. J. Sea Res. 27: 57-71

Moodley, L., Hess, C. (1992). Tolerance of infaunal benthic

This article was presented by J. Gray (Senior Editorial Advisor), Oslo, Norway foraminifera for low and high oxygen concentrations. Biol. Bull. 183: 94-98

Murray, J. W. (1985). Recent foraminifera from the North Sea (Forties and Ekofisk areas) and the continental shelf west of Scotland. J. Micropalaeontol. 4: 117-125

Murray, J. W. (1991). Ecology and palaeoecology of benthic foraminifera. Longman Scientific \& Technical Publishing, Harlow

Murray, J. W. (1992). Distribution and population dynamics of benthic foraminifera from the southern North Sea. J. Foram. Res. 22: 114-128

Nagy, J. (1992). Environmental significance of foraminiferal morphogroups in Jurassic North Sea deltas. Palaeogeogr. Palaeoclimatol. Palaeoecol. 95: 111-134

Palmer, M. A., Molloy, R. M. (1986). Water flow and the vertical distribution of meiofauna: a flume experiment. Estuaries 9: 225-228

Rathburn, A. E., Corliss, B. H. (1994). The ecology of living (stained) deep-sea benthic foraminifera from the Sulu Sea. Paleoceanography 9: 87-150

Sen Gupta, B. K., Machain-Castillo, M. L. (1993). Benthic foraminifera in oxygen-poor habitats. Mar. Micropaleontol. 20: 183-201

Sen Gupta, B. K., Shin, I. C., Wendler, S. T. (1987). Relevance of specimen size in distribution studies of deep-sea benthic foraminifera. Palaios 2: 332-338

Severin, K. P., Erskian, M. G. (1981). Laboratory experiments on the vertical movement of Quinqueloculina impressa Reuss through sand. J. Foram. Res. 11: 133-136

Shirayama, Y. (1984). The abundance of deep sea meiobenthos in the Western Pacific in relation to environmental factors. Oceanologica Acta 7: 113-121

Sjoerdsma, P. G., van der Zwaan, G. J. (1992). Simulating the effect of changing organic flux and oxygen content on the distribution of benthic foraminifera. Mar. Micropaleontol. 19: $163-180$

Verhallen, P. J. J. M. (1986). Morphology and function of the internal structures of non-costate Bulimina. Proc. K. Ned. Akad. Wet. Ser. B 89: 367-385

Manuscript first received: June 21, 1994

Revised version accepted: September 15, 1994 